\title{
A SZEMCSEMÉRET ÉS A MECHANIKAI TULAJDONSÁGOK KAPCSOLATÁNAK VIZSGÁLAT A HEGESZTETT VARRATOKNÁL
}

\section{INVESTIGATION OF THE RELATION BETWEEN THE GRAIN SIZE AND THE MECHANICAL PROPERTIES IN CASE OF WELDED JOINTS}

\author{
Kovács-Coskun Tünde ${ }^{1}$, Pinke Péter ${ }^{2}$, Bitay Enikő ${ }^{3}$ \\ ${ }^{1}$ Óbudai Egyetem, Bánki Donát Gépész és Biztonságtechnikai Mérnöki Kar, Anyag- \\ tudományi és Gyártástechnológiai Intézet, 1081, Magyarország, Budapest, Népszín- \\ ház u. 8; Telefon / Fax: +36-1-6665368, kovacs.tunde@bgk.uni-obuda.hu
}

\author{
${ }^{2}$ Szlovák Müszaki Egyetem Pozsony, Anyagtechnolóogiai Kar Nagyszombat, \\ Paulinska 16,91724Trnava,Szlovákia, peter.pinke@stuba.sk \\ ${ }^{3}$ Sapientia Erdélyi Magyar Tudományegyetem, Müszaki és Humántudományi Kar, \\ Gépészmérnöki Tanszék, Marosvásárhely,O.p.9, C.p.4, ebitay@ms.sapientia.ro
}

\begin{abstract}
It knows that between the grain size and the mechanical properties can find relation [1]. The Hall-Petch equation shows a relationship between the grain size and the yield strength. This equation valuable in case of low carbon steels. Also in the literature we can find a linear function to numerate the yield strength from the hardness. We made some welding samples and measured the hardness and the grain size in the welded joint and the heat affected zone. We find a strong correlation between the grain size and the hardness in case of the tested steel. We supposed in base of our results that we can find a correlation between the grain size and the yield strength too. The hardness test is very quick and simple test what we use always to control the quality of the welded joint and the heat affected zone. If our supposition is real and we can find a correlation between the hardness and the yield strength it can be very usefully during the design of the welding technology.
\end{abstract}

Keywords: Hall-Petch-equation, grain size, hardness, yield strength

\section{Összefoglalás}

A fémes anyagoknál ismert, hogy mechanikai tulajdonságaikra a szemcseméretnek jelentős hatása van [1]. A Hall-Petch-egyenlet a szemcseméret és a folyáshatár közötti összefüggést írja le. Ebben a cikkben kísérletet tettünk, gyakorlati méréseket felhasználva arra, hogy kapcsolatot teremtsünk a szemcseméret, a keménység, valamint a folyáshatár között a Hall-Petch-egyenlet felhasználásával. A szemcseméreteket egy alacsony karbontartalmú acél hegesztett kötésében, illetve höhatásövezetében mértük. A vizsgált acélminőség esetében egyértelmű kapcsolatot tapasztaltunk a keménység és a szemcseméret között.

Ennek alapján feltételezhető, hogy a hegesztett kötés különböző részein a folyáshatár értéke is megváltozik az alapanyaghoz képest. A keménységmérés igen gyors és egyszerü vizsgálati mód, amit a hegesztett varratok ellenőrzése során egyébként is alkalmaznak. Felvázoltunk egy összefüggést, amely alapján a keménységből a folyáshatár meghatározható, ez a gyakorlatban hasznos lehet a méretezés és a kötés szilárdságának ellenőrzése során.

Kulcsszavak: Hall-Petch-egyenlet, szemcseméret, keménység, folyáshatár 


\section{Bevezetés}

A gépészeti tervezési gyakorlat során gyakorta hivatkozunk a Hall-Petchösszefüggésre annak igazolásaként, hogy a mechanikai tulajdonságok és a szemcseméret szoros összefüggésben vannak, ezért a hőkezelés, hegesztés és más technológiák tervezése során igyekszünk a szemcsedurvulást elkerülni, finomszemcsés szerkezetet beállítani. Kísérletekkel igazolható, akár egy szokványos szakítóvizsgálattal is, hogy különböző szemcseméretü próbatesteket alkalmazva ez az összefüggés helytálló. Sajnos az irodalomban a Hall-Petchegyenlet technológiai tervezés során való gyakorlati alkalmazásáról kevés szó esik.

Tanulmányunkban egy gyakorlati méréssorozat alapján arra kerestük a választ, hogy egy egyszerü keménységmérést elvégezve, hogyan kaphatunk a hegesztett kötés méretezéséhez segítséget nyújtó szilárdságértéket.

Hegesztési kísérletsorozatot végeztünk vastaglemezek $(8 \mathrm{~mm})$ sarokvarratának hegesztésére. A technológiai paraméterek ellenőrzése miatt a varrat ellenőrzését is elvégeztük, amely mikrocsiszolat szövetszerkezet- és szemcseméret-meghatározásból és keménységmérésből állt. A hegesztett szerkezetek gyártástechnológiájának (paraméterbeállítás) meghatározásakor figyelembe kell venni a höbevitelböl következő átalakulásokat és szemcsedurvulást. Acélok esetében az átalakulási és szemcsedurvulási hajlam függ az elözetes hidegalakítás mértékétől, valamint a választott hegesztési eljárás paramétereitől. A varratok elkészítése során igyekeztünk a változók számát minimálisra csökkenteni, így a vizs- gált hegesztett varratok esetében a paramétereket nem változtattuk, előzetes hidegalakítást pedig nem végeztünk.

A kis szilárdságú, alacsony karbontartalmú acélon végzett keménységmérésből és szemcseméret-meghatározásból kapott adatsorozatot, az irodalomból ismert Hall-Petch- (1), valamint a keménységszilárdság kapcsolatára (2) felállított összefüggéseket felhasználva kíséreltük meg a folyáshatár meghatározását.

\section{A szemcseméret és a mechanikai tulajdonságok kapcsolata}

\subsection{Hall-Petch-összefüggés}

A Hall-Petch-összefüggés (1) kapcsolatot teremt a fémes anyag szemcsemérete és folyáshatára között, amelyből adódóan a folyáshatár és az átlagos szemcseméret négyzetgyöke között fordított arányosság van [2].

$$
R_{e H}=R_{0}+\frac{k}{\sqrt{d}}
$$

Ahol: $k$ anyagtól függő állandó, $d$ átlagos szemcseátmérő, $R_{0}$ (szilárdsági konstans).

\subsection{A szemcseméret-keménység kap- csolata}

Az 1. ábrán látható, hogy a keménység $\left(\mathrm{HB}_{1840 / 2,5 / 30}\right)$ és a folyáshatár $\left(R_{e H}\right)$, valamint a szakítószilárdság között szoros öszszefüggés mutatható ki számos acél, alumínium- és rézötvözet esetén [3]. 


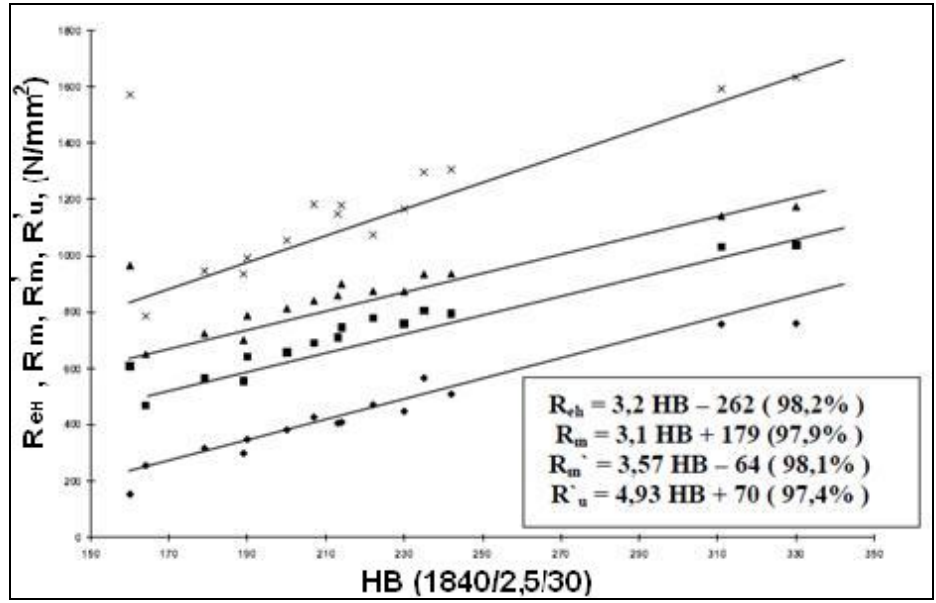

1. ábra. Brinell keménység és a szilárdsági jellemzők kapcsolata [3]

\section{A szemcseméret és a keménység méréssel megállapított értékei}

A szemcseméretet fémmikroszkóppal, a keménységet $\left(\mathrm{HB}_{1840 / 2,5 / 30}\right)$ keménységméréssel határozzuk meg PA helyzetü sarokvarratok esetében, S235JR acélon mérve.

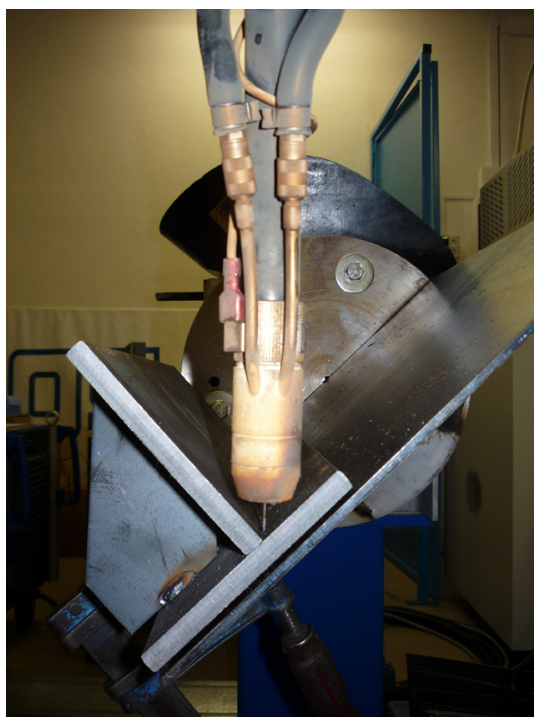

2. ábra. $P A$ helyzetü hegesztés CLOOS Qirox QRC 320 típusú ivhegesztö robottal [1]
A varratokat PA (vályú helyzetü sarokvarrat) helyzetben a 2. ábra szerint hegesztettük MSG normál fogyóelektródás irányított rövidzárlatos védőgázos (Corgon18 védőgáz alkalmazása mellett) ívhegesztési technológiával egy CLOOS Qirox QRC 320 típusú ívhegesztő robottal az Óbudai Egyetem, Bánki Kar CLOOS robothegesztő laborjában. A robothegesztés lehetővé tette, hogy az egyes darabok teljesen azonos beállítások mellett készüljenek el. A kézi hegesztésből adódóan ugyanis bizonyos pontatlanságok, bizonytalanságok származhatnak [4].

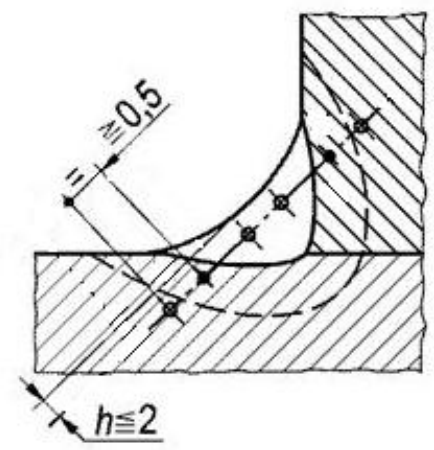

3. ábra. A keménységmérési pontok a varratban és a höhatásövezetben 
A mérési eredményeket az 1. táblázat foglalja össze. A keménységértékek, valamint a szemcseméretek a varratban azonos koordináták mentén két azonos elrendezésű és azonos technológiával hegesztett sarokvarrat metszetén kerültek meghatározásra.

1. táblázat. Átlagos szemcseméret és a keménység az azonos koordinátájú pontokon mérve

\begin{tabular}{|c|c|}
\hline $\begin{array}{c}\text { Szemcseátmérők } \\
(\boldsymbol{\mu m})\end{array}$ & $\begin{array}{c}\text { Keménységek } \\
\left.\mathbf{( H B}_{\mathbf{1 8 4 0 / 2}, \mathbf{5} / \mathbf{3 0}}\right)\end{array}$ \\
\hline 8,54 & 154,75 \\
\hline 5,62 & 201,25 \\
\hline 5,73 & 193 \\
\hline 8,60 & 158,75 \\
\hline 8,90 & 150 \\
\hline
\end{tabular}

A varratban és a hőhatásövezetben a mérési pontokat a 3. ábra szemlélteti. A keménységmérés eredményeit, valamint a szemcseméretet a varratban, illetve a höhatásövezetben a 4. ábra mutatja.

A 4. ábrán a keménység és a szemcseméret változása szoros korrelációt mutat, melyet lineáris egyenessel közelítettünk, de erre a kapcsolatra egyértelmü függvénykapcsolatot nem tudtunk felírni. Természetesen az elvégzett mérések száma alapján egyértelmüen nem mondható ki, hogy keménység és a szemcseméret között a kapcsolat lineáris. Kutatásaink során tervezzük, ennek nagyszámú kísérletböl és mérési eredményekből történő meghatározását.
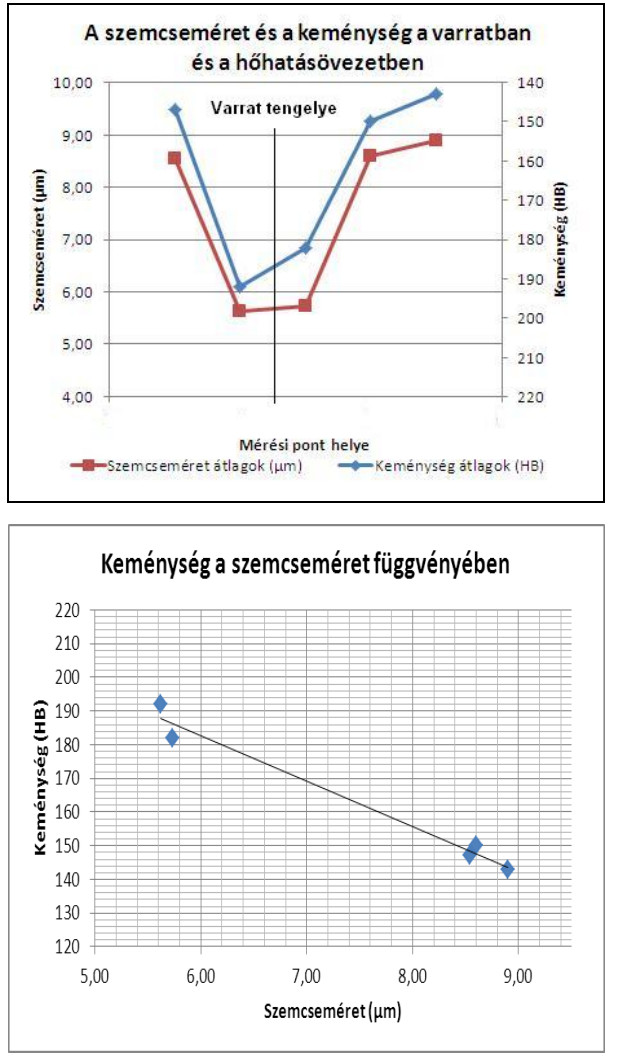

4. ábra. Keménység és a szilárdsági jellemzők kapcsolata [1]

Felhasználva az 1. ábra összefüggéseiből a folyáshatárra vonatkozó egyenletet (2), valamint a Hall-Petch-összefüggést (1), amelyeket ha egymással egyenlővé teszünk, az alábbi (3) összefüggést kapjuk.

$$
\begin{aligned}
& R_{e H}=3,2 \cdot H B-262 \\
& 3,2 \cdot H B-262=R_{0}+k \cdot d^{-\frac{1}{2}}
\end{aligned}
$$

Mérési eredményeink és a belőlük számított keménység-szilárdság értékek lineáris kapcsolatot mutatnak az 5. ábra szerint. 


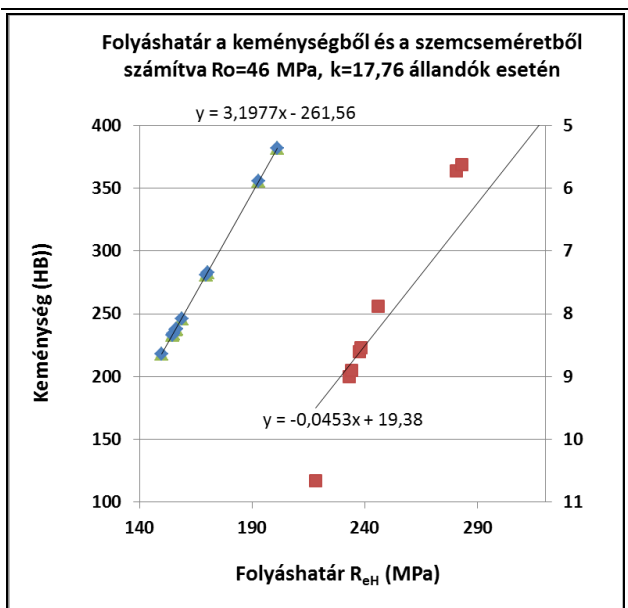

5. ábra. Keménység és a szilárdsági jellemzők kapcsolata az (1) és (2) összefüggések szerint. A 2. táblázat azonos soraiban a felírt (3) összefüggés alapján közel azonos értékeknek kellene szerepelniük, ezzel szemben a varrat közepén, ahol a szemcseméret lecsökkent $(5,62-5,73 \mu \mathrm{m})$, a számított folyáshatár értékek jelentősen eltérnek.

A mérési eredményeinkből kapott függvény az irodalomban talált (2) összefüggéssel közel azonos a keménység és a folyáshatár tekintetében. A Hall-Petchösszefüggés alapján számított értékek szintén illeszkednek egy hatványgörbére, de itt meg kell jegyezni, hogy a számításaink során $R_{0}$ és $k$ értékére az irodalomból átvett közelítő értékeket alkalmaztuk.

A felírt összefüggések segítségével számíthatjuk a folyáshatárt a $k$ tényezőből

2. táblázat. Számitással meghatározható szilárdsági értékek

\begin{tabular}{|c|c|c|c|}
\hline $\begin{array}{l}\text { HB keménységből (2) } \\
\text { számított folyáshatár } \\
\qquad R_{\mathrm{eH}}\left(\mathrm{N} / \mathrm{mm}^{2}\right)\end{array}$ & $\begin{array}{l}\text { Szemcseméret } \\
\text { d }(\mu \mathrm{m})\end{array}$ & $\begin{array}{l}\text { Átlagérték } \\
\text { k [5] }\end{array}$ & $\begin{array}{c}\text { Hall Petch- (1) } \\
\text { összefüggésből számítva } \\
\left(R_{0}=46 \mathrm{MPa}, \mathrm{k}=17,76\right) \\
\mathrm{R}_{\mathrm{eH}}\left(\mathrm{N} / \mathrm{mm}^{2}\right)\end{array}$ \\
\hline 233,2 & 8,54 & \multirow{5}{*}{17,76} & 238,18 \\
\hline 382 & 5,62 & & 282,90 \\
\hline 355,6 & 5,73 & & 280,62 \\
\hline 246 & 8,60 & & 237,51 \\
\hline 218 & 8,90 & & 234,25 \\
\hline
\end{tabular}

\section{Következtetések}

Keménység- és szemcseméret-méréseket végeztünk sarokvarrat hegesztését követően. Az irodalomban található összefüggések alapján kiszámítottuk a lokális folyáshatárt a szemcseméret és a keménység függvényében. A szemcseméretböl és a keménységből meghatározott folyáshatárértékek között eltérést tapasztaltunk. A varrat tengelyétől távolabbi pontokon, ahol a keménység már az alapanyaghoz közeli, a folyáshatár-értékek mind a szemcseméret- ből, mind a keménységből adódóan közel azonos, az alapanyag folyáshatárához közeli eredményt adtak. A varrat tengelyéhez közel, ahol a szemcseméret jelentősen különbözik a hőhatásövezetben találhatótól (olvadékból kristályosodott, dendrites szerkezetü), a keménységből és a szemcseméretből következően jelentősen eltérő eredményt kaptunk. Feltehető, hogy a számításainkban felhasznált állandók $\left(R_{0}, k\right)$ korrekciója szükséges.

$\mathrm{Az}$ általunk megfigyelt keménységszemcseméret közötti kapcsolat nagyszámú 
méréssel történő igazolása vezethet eredményre annak megítélésében, hogy a szemcseméret és a szilárdság közötti összefüggést meghatározhassuk.

\section{Köszönetnyilvánítás}

A szerzők köszönetet kívánnak mondani a Cloos Crown International Kft.-nek, valamint Végh Sándornak a cég munkatársának, aki a hegesztési kísérletekben nyújtott támogatást, valamint Szilágyi Gábor egyetemi hallgatónak, aki a mérésekben segítette munkánkat.

\section{Szakirodalmi hivatkozások}

[1] Szilágyi G., Kovács-Coskun T., Pinke P.: Az összeállitási pontatlanság hatása a hegesztési paraméterek korrekciójára sarokvarratok esetén. FMTÜ XVIII. EME, Kolozsvár, 2013, 383-386.

[3] Krállics Gy., Fodor Á.: A 17-4 PH Martenzites korrózióálló acél fázisátalakulásának vizsgálata dilatométerrel. Anyagvizsgálók lapja 2005/4. 107-109.

[2] Varga Ferenc, Tóth László, Guy Pluvinage: Anyagok károsodása és vizsgálata különbözö üzemi körülmények között. Miskolci Egyetem, 1999. 33.

http://edu.bzlogi.hu/mtesting/szoftverek/kem enys.pdf

[4] Bagyinszki Gy., Bitay E.: Hegesztéstechnika I., EME, Kolozsvár, 2010. 53-68.

[5] Pinke P., Kovács-Coskun T.: Mérnöki anyagtudomány. Példatár II., ÓE egyetemi jegyzet, Budapest, 2012. 32-33. 